\title{
PROFILE OF LUNGS VOLUME IN THE DIABETES MELITUS AND NON DIABETES MELITUS
}

\author{
Litta Marlin Patty, Jodelin Muninggar, Nur Aji Wibowo \\ Physics Education Study Program, Science, Technology and Mathematics Education \\ Center (e-SisTeM) Faculty of Science and Mathematics, Satya Wacana Christian \\ University Diponegoro Street No. 52-60, Salatiga, 50711, Central Java, Indonesia \\ *Email : littampatty@gmail.com
}

\begin{abstract}
International Diabetes Federation states that in 2007 there were 246 million people in the world suffering from diabetes and it is expected to increase to 380 million by 2025 . DM can cause susceptibility to infections in the human lung organs due to hyperglycemia. The purpose of this study was to determine the lung volume profile in the form of VT, VCI, VCE and VKP in the DM group and non DM group. This study uses a quantitative descriptive survey design with a sample of 60 people, consisting of 30 people from the DM group and 30 people from the Non DM group. The statistical test used in this study is the Independent statistical sample t-test, the Mann-Whitney test and the Pearson correlation. The results showed: (1) There was a significant difference in the DM of the DM group and the Non DM group with $\mathrm{p}=0.021$ ( $\mathrm{p}$ $<0.05)$; (2) There were significant differences in VT, VCI, VCE of the DM group and Non DM group with significant values of VT $(p=0,000<0.05)$, VCI $(p=0.003<0.05)$ and $\mathrm{VCE}(\mathrm{p}=$ $0.001<0.05)$; (3) There was no significant difference in the VKP of the DM group and the Non DM group with $\mathrm{p}=0.805(\mathrm{p}<0.05)$; (4) Relationship between GD and VT $(\mathrm{r}=0.220)$, GD with VCI $(r=0.308)$, GD with VCE $(r=-0.110)$, GD with VKP $(r=0.219)$. So it was concluded that there was a positive relationship between GD and VT, VCI, VKP and also there was a negative relationship between GD and VCE. Suggestion: DM sufferers need to conduct routine checks so that health remains well controlled.
\end{abstract}

Keywords: blood sugar, lung volume (VT, VCI, VCE, VKP), Diabetes mellitus

\section{Introduction}

International Diabetes Federation (IDF) states that in 2007 there were 246 million people worldwide suffering from diabetes and is expected to increase to 380 million by 2025. In addition, the incidence rate in 2010 was 285 million or $6.4 \%$ in the population aged 20-79 years of suffering from DM. This figure is expected to increase to 438 million or 7.7\% in the population aged 20-79 years in 2030 (PERKENI, 2011).

International Diabetes Federation (IDF) Atlas 2017 reports that the Diabetes epidemic in Indonesia is still showing an increasing trend. Indonesia is the sixth ranked country in the world after China, India, the United States, Brazil and Mexico with the number of people with diabetes aged 20-79 years around 10.3 million people. In line with this, Basic Health Research (Riskesdas) shows a significant increase in the prevalence of Diabetes, from $6.9 \%$ in 2013 to $8.5 \%$ in 2018 , so the estimated number of sufferers in Indonesia reaches more than 16 million people which is then at risk of other diseases, such as: heart attack, stroke, blindness and kidney failure can even cause paralysis and death (Ministry of Health of the Republic of Indonesia, 2018).

Diabetes mellitus is a group of metabolic diseases characterized by hyperglycemia that occurs due to abnormalities in insulin secretion, insulin performance or both (ADA, 2010). People with diabetes mellitus are vulnerable to infection. Infection can occur due to high blood glucose (hyperglycemia) interfering with the body's immune

Received September $16^{\text {th }} 2019$, Revision January $28^{\text {th }} 2020$, Accepted for publication February $18^{\text {th }} 2020$.

Copyright (C) 2020 Published by FKIP - Unpatti, ISSN 2721-3110 
function in the face of the entry of viruses or bacteria. The lungs are one of the body's organs that are susceptible to infection (Ndraha, 2014). Decreased lung function that occurs suddenly can cause a condition called respiratory failure and can cause death to sufferers (Blodshine, 2000). To find out a person's pulmonary function is in a normal or abnormal condition, lung function testing must be done using spirometry devices.

Spirometry is an examination technique to determine the function / function of the lungs, in which patients are asked to blow according to the lung volume to be measured ie tidal volume, the volume of inspiration reserve, expiratory reserve volume and vital lung capacity with a device that is connected to the spirometer that will automatically calculate the strength, speed and volume of air released, so that it can be known the condition of one's lung physiology (Sherwood, 2001). Spirometer uses the principle of one of the laws in physics which is the law of Archimedes. This is reflected when the spirometer is blown, when the tube containing the air will go up and down because of the upward force due to pressure from the air entering the spirometer (Blondshine, 2000).

Spirometry testing is important in detecting several disorders related to respiratory disorders and can be used to screen for lung disease. Another indication of the use of spirometry is to determine the strength and function of the chest muscles and it is important to assess its weight obstruction, weight restriction and treatment effect. Many patients without complaints, but the spirometry examination shows obstruction or restriction and this can be used as an early warning for impaired lung function that may occur so that precautions can be determined as soon as possible. Spirometry records graphically or digitally the volume of forced expiration and forced vital capacity (Alasagaff, 2005).

Based on the background above, the problem of this study is what is the lung volume profile (tidal volume, inspiration reserve volume, expiratory reserve volume, lung capacity volume) in the DM and Non DM groups? The purpose of this study are (1) to determine the differences in GD and lung volume in the DM group and the Non DM group. (2) determine the relationship of blood glucose with lung volume. The success of this research will assist health workers in overcoming and managing respiratory disorders in diabetes mellitus. Besides the results of spirometry examination can be used as a data base in managing patients with diabetes mellitus (DM) with pulmonary physiology.

\section{Methods}

The design of this study is a quantitative descriptive survey using a cross sectional approach, which is a type of research that emphasizes the measurement / observation of data only once at a time (Nursalam, 2011). The research at the Damatex Clinic was conducted at the end of November 2018 and the UKSW Clinic was conducted in December 2018. The population of this study was the DM group and the Non DM group who were in the Damatex Clinic and the UKSW Clinic in Salatiga City. The sampling technique used was purposive sampling, thus the sample in this study amounted to 60 people, consisting of 30 people from the DM group and 30 people from the Non DM group. The blood glucose measurement instrument uses a Nesco blood sugar level measurement and lung volume measurement uses a spirometry device.

The statistical methods used are (1) Descriptive analysis, aimed at describing blood glucose and lung volume data in the DM and Non DM groups that will be displayed in the form of frequency / curve distribution; (2) The unpaired $\mathrm{T}$ test is a parametric test (normal data distribution). This test is used to determine differences in blood glucose and lung volume in the DM and Non DM groups. However, if the data distribution is not normal, the Mann-Whitney test can be used as an alternative (Dhalan, 2008). The requirements for the unpaired $T$ test are: Data must be normally distributed (required) data variants may be the same, may not be the same. The degree of significance $(\alpha)$ is 0.05 ; (3) Pearson Correlation Test. This test is used to determine the

Received September $16^{\text {th }} 2019$, Revision January $28^{\text {th }} 2020$, Accepted for publication February $18^{\text {th }} 2020$.

Copyright (C) 2020 Published by FKIP - Unpatti, ISSN 2721-3110 
relationship of blood glucose with lung volume. So that the strength of the relationship can be obtained positively or negatively (Sugiyono, 2012). This research was analyzed using the help of the Statistical Program for Social Science (SPSS) computer program version 20.0 .

\section{Results}

\section{Characteristics of Respondents}

Study the characteristics studied included age, sex, education, and occupation. Respondents in this study were 60 people. Data on the characteristics of respondents can be seen in the table below:

Table 1. The frequency distribution of respondents was based on age, gender, education, and occupation at the Damatex Clinic and the UKSW Clinic Salatiga City in 2018 (N = $60)$.

\begin{tabular}{|c|c|c|c|c|c|}
\hline \multirow{2}{*}{\multicolumn{2}{|c|}{ Variabel }} & \multicolumn{2}{|c|}{ Group DM } & \multicolumn{2}{|c|}{ Group Non DM } \\
\hline & & Frekuensi & $\%$ & Frekuensi & $\%$ \\
\hline \multirow{4}{*}{ Age } & 20-40 Years & 0 & 0.0 & 9 & 30.0 \\
\hline & 41-65 Years & 22 & 73.3 & 15 & 50.0 \\
\hline & $>66$ Years & 8 & 26.7 & 6 & 20.0 \\
\hline & Total & 30 & 100.0 & 30 & 100.0 \\
\hline Type & Genital & 15 & 50.0 & 5 & 16.7 \\
\hline \multirow{2}{*}{ Male } & Girl & 15 & 50.0 & 25 & 83.3 \\
\hline & Total & 30 & 100.0 & 30 & 100.0 \\
\hline \multirow{5}{*}{ Elementary } & Education & 4 & 13.3 & 0 & 0.0 \\
\hline & Middle school & 1 & 3.3 & 3 & 10.0 \\
\hline & High school & 19 & 63.3 & 22 & 73.3 \\
\hline & Higher Education & 6 & 20.0 & 5 & 16.7 \\
\hline & Total & 30 & 100.0 & 30 & 100.0 \\
\hline \multirow{6}{*}{ Employment } & Private Employees & 17 & 56.7 & 10 & 33.3 \\
\hline & Labor & 5 & 16.7 & 0 & 0.0 \\
\hline & Retired & 5 & 16.7 & 4 & 13.3 \\
\hline & Housewife & 3 & 10.0 & 11 & 36.7 \\
\hline & Student & 0 & 0.0 & 5 & 16.7 \\
\hline & Total & 30 & 100.0 & 30 & 100.0 \\
\hline
\end{tabular}

Source: SPPS data processing results, 2018.

The output results above indicate that the DM group respondents in this study were dominated by ages 41-65 years, namely 22 people or equal to (73.3\%), male and female gender equal or equal to $(50.0 \%)$, with a high school education level of 19 people (63.3\%), and private sector employment 17 people (56.7\%). While the Non-DM group in this study was dominated by age 41-65 years, namely 15 people $(50.0 \%)$, female sex numbered 25 people (83.3\%), with a high school education level of 22 people $(73.3 \%)$, as well as housewife occupation 11 people (36.7\%).

\section{Normality test}

The normality test is performed as a condition of the unpaired T Test statistic. Data is declared normal if $p>0.05$ and said to be abnormal if $p<0.05$. Normality test is performed using the Shapiro-Wilk formula (sample <50). However, if the data distribution is not normal, then the Mann-Whitney alternative test can be used. A summary of the results of the normality test can be seen in the following table:

Received September $16^{\text {th }} 2019$, Revision January $28^{\text {th }} 2020$, Accepted for publication February $18^{\text {th }} 2020$. 
Table 2. Test results for the normality of the variables GD, VT, VCI, VCE and VKP

\begin{tabular}{clccccccc}
\hline & \multicolumn{7}{c}{ Tests of Normality } \\
\hline \multirow{2}{*}{ Variabel } & \multirow{2}{*}{ Group } & \multicolumn{2}{c}{ Kolmogorov- $^{2}$ Shapiro-Wilk } & \multirow{2}{*}{ Information } \\
\cline { 3 - 8 } & & Statistic & df & Sig. & Statistic & df & Sig. & \\
\hline \multirow{2}{*}{ GD } & Group DM & .208 & 30 & .002 & .886 & 30 & .004 & Abnormal \\
\cline { 2 - 8 } & Group Non DM & .114 & 30 & $.200^{*}$ & .948 & 30 & .149 & Normal \\
\hline \multirow{2}{*}{ VT } & Group DM & .224 & 30 & .001 & .903 & 30 & .010 & Abnormal \\
\cline { 2 - 8 } & Group Non DM & .119 & 30 & $.200^{*}$ & .975 & 30 & .673 & Normal \\
\hline \multirow{2}{*}{ VCI } & Group DM & .137 & 30 & .156 & .948 & 30 & .146 & Normal \\
\cline { 2 - 8 } & Group Non DM & .173 & 30 & .022 & .914 & 30 & .018 & Abnormal \\
\hline \multirow{2}{*}{ VCE } & Group DM & .127 & 30 & $.200^{*}$ & .909 & 30 & .014 & Abnormal \\
\cline { 2 - 8 } & Group Non DM & .131 & 30 & $.200^{*}$ & .949 & 30 & .160 & Normal \\
\hline \multirow{2}{*}{ VKP } & Group DM & .103 & 30 & $.200^{*}$ & .975 & 30 & .695 & Normal \\
\cline { 2 - 7 } & Group Non DM & .111 & 30 & $.200^{*}$ & .948 & 30 & .150 & Normal \\
\hline
\end{tabular}

Source: SPPS data processing results, 2018.

Shapiro-Wilk normality test results obtained that the VKP variable has normal data distribution $(p>0.05)$ and the GD, VT, VCI, VCE variables have abnormal data distribution $(\mathrm{p}<0.05)$, so that data transformation must be done to reduce the scale of the data size so that the data can normally distributed. If after transforming the data and it is found that the results of the data have not been distributed normally, then the statistical test can then be used Mann-Whitney alternative test. Data normality test results after the data is transformed can be seen in the table below:

Table 3. Results of normality testing after data transformation in the Damatex Clinic and the UKSW Clinic Salatiga City in $2018(\mathrm{~N}=60)$.

\begin{tabular}{|c|c|c|c|c|c|c|c|c|}
\hline \multicolumn{9}{|c|}{ Tests Of Normality After Data Transformation } \\
\hline \multirow[t]{2}{*}{ Variabel } & \multirow[t]{2}{*}{ Grouping } & \multicolumn{3}{|c|}{$\begin{array}{l}\text { Kolmogorov- } \\
\text { Smirnov }^{\mathrm{a}}\end{array}$} & \multicolumn{3}{|c|}{ Shapiro-Wilk } & \multirow[t]{2}{*}{ Information } \\
\hline & & Statistic & $\mathrm{df}$ & Sig. & Statist & $\mathrm{df}$ & Sig. & \\
\hline GD & Group DM & .152 & 30 & .076 & .936 & 30 & .070 & Normal \\
\hline Trans & Group Non DM & .091 & 30 & $.200^{*}$ & .974 & 30 & .668 & Normal \\
\hline VT & Group DM & .272 & 30 & .000 & .764 & 30 & .000 & Abnormal \\
\hline Trans & Group Non DM & 277 & 30 & .000 & .672 & 30 & .000 & Abnormal \\
\hline VCI_ & Group DM & .251 & 30 & .000 & .820 & 30 & .000 & Abnormal \\
\hline Trans & Group Non DM & .184 & 30 & .011 & .897 & 30 & .007 & Abnormal \\
\hline VCE & Group DM & .164 & 30 & .038 & .895 & 30 & .006 & Abnormal \\
\hline Trans & Group Non DM & .133 & 30 & .189 & .965 & 30 & .422 & Normal \\
\hline
\end{tabular}

Source: SPPS data processing results, 2018.

The results of Shapiro-Wilk normality test after the data were transformed obtained GD variable normally distributed $(\mathrm{p}>0.05)$ and VT, VCI, VCE variables not normally distributed $(\mathrm{p}<0.05)$. It can be concluded that for the GD and VKP variables a statistical test can be used for the unpaired T test and for the VT, VCI, VCE variables using the alternative Mann-Whitney test.

Received September $16^{\text {th }} 2019$, Revision January $28^{\text {th }} 2020$, Accepted for publication February $18^{\text {th }} 2020$.

Copyright (C) 2020 Published by FKIP - Unpatti, ISSN 2721-3110 


\section{Analysis of Differences in GD Values in the DM and Non-DM Groups in the Damatex Clinic and the UKSW Clinic in Salatiga City.}

The results of research on the analysis of differences in GD values in the DM and Non DM groups in the Damatex Clinic and the UKSW Clinic in Salatiga City can be seen in the table below:

Table 4. The GD value is the result of data transformation in the DM and Non DM groups in the Damatex Clinic and the UKSW Clinic in Salatiga City in 2018 (N = $60)$.

\begin{tabular}{cccccc}
\hline Variabel & Grouping & $\mathrm{N}$ & Mean & $\begin{array}{c}\text { Std. } \\
\text { Deviation }\end{array}$ & $\begin{array}{c}\text { Std. Error } \\
\text { Mean }\end{array}$ \\
\hline GD_Trans & Group DM & 30 & 1.4756 & .05957 & .01088 \\
\cline { 2 - 6 } & Group Non DM & 30 & 1.4479 & .02049 & .00374 \\
\hline
\end{tabular}

Source: SPPS data processing results, 2018.

The results of the above study show the average value of GD (transformation results) DM group is 1.4756 with a standard deviation $=0.05957$ higher than the average value of the Non DM group that is 1.4479 with a standard deviation $=0.02049$. The difference test results using the Independent-Sample T Test statistical test can be displayed in the table below:

Table 5. Independent Samples Test Statistics Results for the DM and Non DM groups in the Damatex Clinic and the UKSW Clinic Salatiga City in $2018(\mathrm{~N}=60)$.

\begin{tabular}{|c|c|c|c|c|c|c|c|c|}
\hline \multicolumn{9}{|c|}{ Independent Samples Test } \\
\hline & \multirow{3}{*}{ Variabel } & \multicolumn{2}{|c|}{$\begin{array}{c}\text { Levene's Test for } \\
\text { Equality of } \\
\text { Variances }\end{array}$} & \multicolumn{5}{|c|}{$\begin{array}{l}\text { t-test for Equality } \\
\text { of Means }\end{array}$} \\
\hline & & \multirow[t]{2}{*}{$\mathrm{F}$} & \multirow[t]{2}{*}{ Sig. } & \multirow[t]{2}{*}{$\mathrm{T}$} & \multirow[t]{2}{*}{ Df } & \multirow[t]{2}{*}{$\begin{array}{l}\text { Sig. (2- } \\
\text { tailed) }\end{array}$} & \multicolumn{2}{|c|}{$\begin{array}{l}95 \% \text { Confidence } \\
\text { Interval of the } \\
\text { Difference }\end{array}$} \\
\hline & & & & & & & Lower & Upper \\
\hline GD & $\begin{array}{l}\text { Equal } \\
\text { variances } \\
\text { assumed }\end{array}$ & 46.627 & .000 & 2.407 & 58 & .019 & .00467 & .05071 \\
\hline $\begin{array}{l}\text { Tran } \\
\mathrm{s}\end{array}$ & $\begin{array}{l}\text { Equal } \\
\text { variances } \\
\text { not } \\
\text { assumed }\end{array}$ & & & 2.407 & 35.766 & .021 & .00436 & .05102 \\
\hline
\end{tabular}

Source: SPPS data processing results, 2018.

The statistical test results obtained the value of $t$ is 2.407 with a significance level of $p=$ 0.021 . These results indicate that $\mathrm{p}<0.05$, it can be concluded that there is a significant difference in the value of GD transformation between the DM group and the Non DM group.

Received September $16^{\text {th }} 2019$, Revision January $28^{\text {th }} 2020$, Accepted for publication February $18^{\text {th }} 2020$. 


\section{a. Analysis of Differences in Values of VT, VCI, VCE in the DM and Non DM Groups in the Damatex Clinic and the UKSW Clinic in Salatiga City.}

The results of research on the analysis of differences in VT, VCI, VCE values in the DM group and the Non DM group in the Damatex Clinic and the UKSW Clinic in Salatiga City can be seen in the table below:

Table 6. The Mann-Whitney statistical test of VT, VCI \& VCE variables resulting from data transformation in the DM and Non DM groups in the Damatex Clinic and the UKSW Clinic in Salatiga in $2018(\mathrm{~N}=60)$.

\begin{tabular}{|c|c|c|c|c|c|c|}
\hline Variabel & Grouping & $\mathrm{N}$ & $\begin{array}{l}\text { Mean } \\
\text { Rank }\end{array}$ & $\begin{array}{c}\text { Sum of } \\
\text { Ranks }\end{array}$ & $\begin{array}{c}\text { Mann- } \\
\text { Whitney U }\end{array}$ & $\begin{array}{l}\text { Asymp. } \\
\text { Sig. (2- } \\
\text { tailed) }\end{array}$ \\
\hline VT & Group DM & 30 & 20.62 & 618.50 & \multirow{2}{*}{153.500} & \multirow{2}{*}{.000} \\
\hline Trans & Group Non DM & 30 & 40.38 & 1211.50 & & \\
\hline VCI & Group DM & 30 & 37.22 & 1116.50 & \multirow{2}{*}{248.500} & \multirow{2}{*}{.003} \\
\hline Trans & Group Non DM & 30 & 23.78 & 713.50 & & \\
\hline VCE & Group DM & 30 & 23.05 & 691.50 & \multirow{2}{*}{226.500} & \multirow{2}{*}{.001} \\
\hline Trans & Group Non DM & 30 & 37.95 & 1138.50 & & \\
\hline
\end{tabular}

Source: SPPS data processing results, 2018.

Based on the output of "Test Statistics" it is known: (1) The average VT value of the DM group (20.62) is lower than the average VT value of the Non DM group (40.38). MannWhitney test results obtained $\mathrm{p}=0.000<0.05$, it concluded that there were significant differences in the VT value of the DM group and the Non DM group; (2) The average VCI value of the DM group (37.22) is higher than the average VCI value of the Non DM group (3.78). Mann-Whitney test results obtained $p=0.003<0.05$, then concluded that there is a significant difference in the value of the VCI DM group and Non DM group; (3) The average VCE value of the DM group (23.05) is lower than the average value of the VCE Non DM group (37.95). Mann-Whitney test results obtained $p=0.001<0.05$, it concluded that there were significant differences in the value of the VCE DM group and Non DM group.

\section{b. Analysis of the Difference in VKP Values in the DM and Non DM Groups in the Damatex Clinic and the UKSW Clinic in Salatiga City.}

The results of the study on the Analysis of the Difference in VKP Values in the DM and Non DM Groups in the Damatex Clinic and the UKSW Clinic Salatiga City can be seen in the table below:

Table 7. VKP Value in the DM Group and Non-DM Group in the Damatex Clinic and the UKSW Clinic in Salatiga City in $2018(\mathrm{~N}=60)$.

\begin{tabular}{cccccc}
\hline Variabel & Grouping & N & Mean & Std. Deviation & $\begin{array}{c}\text { Std. Error } \\
\text { Mean }\end{array}$ \\
\hline \multirow{2}{*}{ VKP } & Group DM & 30 & 478.4333 & 208.17958 & 38.00822 \\
\cline { 2 - 6 } & Group Non DM & 30 & 493.0333 & 247.24977 & 45.14142 \\
\hline
\end{tabular}

Source: SPPS data processing results, 2018.

Received September $16^{\text {th }} 2019$, Revision January $28^{\text {th }} 2020$, Accepted for publication February $18^{\text {th }} 2020$.

Copyright (C) 2020 Published by FKIP - Unpatti, ISSN 2721-3110 
The results of the above study show the average value of the DM group VKP is 478.4333 with a standard deviation $=208.17958$ lower than the average VKP value of the Non DM group that is 493.0333 with a standard deviation $=247.24977$. The difference test results using the Independent-Sample T Test statistical test can be displayed in the table below:

Table 8. Independent Samples Test Results in the DM and Non-DM Groups in the Damatex Clinic and the UKSW Clinic Salatiga City in $2018(\mathrm{~N}=60)$.

\begin{tabular}{|c|c|c|c|c|c|c|c|c|}
\hline \multicolumn{9}{|c|}{ Independent Samples Test } \\
\hline & \multirow[t]{3}{*}{ Variabel } & \multicolumn{2}{|c|}{$\begin{array}{c}\text { Levene's } \\
\text { Test for } \\
\text { Equality of } \\
\text { Variances }\end{array}$} & \multicolumn{5}{|c|}{$\begin{array}{l}\text { t-test for Equality } \\
\text { of Means }\end{array}$} \\
\hline & & \multirow[t]{2}{*}{$\mathrm{F}$} & \multirow[t]{2}{*}{ Sig. } & \multirow[t]{2}{*}{$\mathrm{T}$} & \multirow[t]{2}{*}{ Df } & \multirow{2}{*}{$\begin{array}{l}\text { Sig. }(2- \\
\text { taile) }\end{array}$} & \multicolumn{2}{|c|}{$\begin{array}{l}95 \% \text { Confidence Interval of } \\
\text { the Difference }\end{array}$} \\
\hline & & & & & & & Lower & Upper \\
\hline \multirow[b]{2}{*}{ VKP } & $\begin{array}{l}\text { Equal } \\
\text { variances } \\
\text { assumed }\end{array}$ & .569 & .454 & -.247 & 58 & .805 & -132.72462 & 103.52462 \\
\hline & $\begin{array}{l}\text { Equal } \\
\text { variances } \\
\text { not } \\
\text { assumed }\end{array}$ & & & -.247 & 56.365 & .805 & -132.79762 & 103.59762 \\
\hline
\end{tabular}

Source: SPPS data processing results, 2018.

The statistical test results obtained by the $t$ value is -0.247 with a significance level of $p=$ 0.805 . These results indicate that $\mathrm{p}>0.05$, it can be concluded that there is no significant difference in the value of VKP between the DM group and the Non DM group.

\section{c. Correlation Analysis of GD with VT, VCI, VCE and VKP in the Damatex Clinic and the UKSW Clinic in Salatiga City.}

The results of research on the Correlation Analysis of GD with VT, VCI, VCE and VKP in the Damatex Clinic and the UKSW Clinic in Salatiga City can be seen in the table below:

Table 9. Pearson Correlation Test for the DM Group and Non-DM Group in the Damatex Clinic and the UKSW Clinic Salatiga City in $2018(\mathrm{~N}=60)$.

\begin{tabular}{|c|c|c|c|c|c|}
\hline \multicolumn{5}{|c|}{ Correlations } \\
\hline & VARIABEL & VT & VCI & VCE & VKP \\
\hline \multirow{3}{*}{ GD_Trans } & Pearson Correlation & .220 & $.308^{*}$ & -.110 & .219 \\
\cline { 2 - 6 } & Sig. (2-tailed) & .091 & .017 & .404 & .093 \\
\cline { 2 - 6 } & $\mathrm{N}$ & 60 & 60 & 60 & 60 \\
\hline
\end{tabular}

Source: SPPS data processing results, 2018.

Output the table above it can be seen: (1) The relationship between GD and VT obtained $\mathrm{p}$ value $=0.091(\mathrm{p}>0.05)$ and $\mathrm{r}$ count is 0.220 . Then it can be concluded that GD is positively related to VT with a weak correlation degree. (2) The relationship between GD and VCI obtained the value of $p=0.017(p<0.05)$ and $r$ count is 0.308 . It can be concluded that GD is positively and significantly related to VCI with the degree of correlation of weak correlation. (3) The relationship between GD and VCE obtained the value of $p=0.404(p>0.05)$ and $r$ count is -0.110 . It can be concluded that GD is negatively related to VCE with the degree of correlation of weak correlation. (4) The

Received September $16^{\text {th }} 2019$, Revision January $28^{\text {th }} 2020$, Accepted for publication February $18^{\text {th }} 2020$.

Copyright (C) 2020 Published by FKIP - Unpatti, ISSN 2721-3110 
relationship between GD and VKP obtained the value of $p=0.093(p>0.05)$ and the $r$ count is 0.219 . Then it can be concluded that GD is positively related to VKP with the degree of correlation of weak correlation.

\section{Discussion}

\section{a. Analysis of Differences in GD Values in the DM and Non-DM Groups at the Damatex Clinic and the UKSW Clinic in Salatiga City.}

It can be seen that the average value of the DM DM group is higher than the average value of the Non DM DM group that is 1.4756 with a standard deviation = 0.05957. Independent Samples Test results obtained t value of 2.407 with a significance level of $p=0.021$. These results indicate that $p<0.05$, so it can be concluded that there is a significant difference in the value of GD transformation results between the DM group and the Non DM group in the Damatex Clinic and the UKSW Clinic in Salatiga City.

Indonesia is a country that has experienced an increase in the prevalence of patients who have quite high blood sugar levels due to the existence of excessive lifestyles and eating patterns that cause metabolic disorders (MOH RI, 2008). Diabetes mellitus or diabetes is also defined as a chronic disease characterized by an increase in blood glucose levels when equal to or more than $200 \mathrm{mg} / \mathrm{dl}$, and fasting blood sugar levels above or equal to $126 \mathrm{mg} / \mathrm{dl}$ (Misnadiarly, 2006). Glucose is a fraction of carbohydrates that the body will absorb in the bloodstream, glucose acts as the main fuel in the body, whose function is to produce energy (Amir, 2015).

Blood glucose is influenced by several factors including wrong diet, medication, age, and lack of activity and so forth. Diet is defined as a form of food consumption habits in a person in daily life, wrong eating patterns are one of the triggers for diabetes mellitus (DM). For this reason, it is necessary to have a meal plan by following the $3 \mathrm{~J}$ principle (exact number, type, and schedule) so that blood sugar levels remain under control (Syauqy, 2015). An increase in blood sugar levels is closely related to age, so the prevalence of type 2 diabetes will increase along with increasing age and result in higher glucose tolerance disorders. At the age of $>30$ years the aging process that takes place results in changes in body anatomy, bodily functions and biochemistry (Sudoyo, 2009). Diabetes will usually arise when you have entered a vulnerable age, ie age $>45$ years who are overweight, so that insulin in the body is not sensitive. Existing theory says that degenerative factors namely decreased body function that occurs in someone $\geq 45$ years can experience an increased risk of diabetes mellitus and glucose intolerance, especially the ability of $\beta$ cells in glucose metabolism for insulin production (Pangemanan, 2014).

According to Sutanto (2010) that someone who has a sibling with type II diabetes has a much higher risk of becoming diabetic. In the study of Nezhad et al, 2008 there were differences in the percentage of people with diabetes mellitus between men and women. The percentage of diabetics in men is $5.1 \%$ while in women it is $5.8 \%$. This is in accordance with the statement of Taylor (2010), which states that the cause of women affected by type 2 diabetes mellitus due to a decrease in the hormone estrogen, especially during menopause. when menopause occurs, the insulin response decreases due to low estrogen and progesterone. changes in the body's hormone levels can trigger fluctuations in blood sugar levels. This causes blood sugar levels more difficult to predict than before menopause. If blood sugar levels are not controlled, it will have a higher risk of diabetes complications.

Received September $16^{\text {th }} 2019$, Revision January $28^{\text {th }} 2020$, Accepted for publication February $18^{\text {th }} 2020$. 


\section{b. Analysis of Differences in Values of VT, VCI \& VCE in the DM and Non DM Groups in the Damatex Clinic and the UKSW Clinic in Salatiga City.}

It can be seen that the average VT value of the Non DM group is higher than the average VT value of the DM group that is 40.38 . The average VCI value of the DM group is higher than the average value of the Non DM group VCI that is 37.22 and the average VCE value of the Non DM group is higher than the average value of the DM group VCE that is 37.95. Mann-Whitney test results obtained significance values VT $(p=0.000)$, VCI $(p=0.003)$ and VCE $(p=0.001)$. The results show that $p<0.05$, so it can be concluded that there are significant differences in the value of VT, VCI, VCE DM groups and Non DM groups in the Damatex Clinic and the UKSW Clinic in Salatiga City.

The lungs have the function of exchanging gases of oxygen and carbon dioxide. Oxygen, which is combined with carbon and hydrogen from tissues, allows each cell to carry out metabolic processes and the results of processes in the form of carbon dioxide can be removed from the body (Pearce, 2008). Pulmonary volume is an anatomical and physiological measurement that is affected by physical exercise and disease. Normal values of $\mathrm{VT}= \pm 500 \mathrm{ml}, \mathrm{VCI}= \pm 3000 \mathrm{ml}$ and $\mathrm{VCE}= \pm 1100 \mathrm{ml}$ (Guyton, 2007).

Diabetes mellitus can increase the frequency and severity of an infection. This is caused by abnormalities in the immune system that cause a decrease in phagitosis function so that it is more easily infected with TB (Cahyadi et al., 2011). Some studies reveal that DM is one of the risk factors for TB (Elorriaga et al., 2014). The results of the study by Livia et al. (2015) showed that of the 738 DM patients examined at Hasan Sadikin Hospital in Bandung, 28\% had TB and 9.3\% had a history of TB.

\section{c. Analysis of the Difference in VKP Values in the DM and Non DM Groups in the Damatex Clinic and the UKSW Clinic in Salatiga City.}

It can be seen that the average VKP value of the Non DM group is higher than the average VKP value of the DM group that is 493,0333 with a standard deviation = 247,24977. Independent Samples Test results obtained $t$ value of -0.247 with a significance level of $p=0.805$. These results indicate that $p>0.05$, so it can be concluded that there is no significant difference in the VKP value of the DM group and the Non DM group in the Damatex Clinic and the UKSW Clinic in Salatiga City.

The volume of lung capacity is the maximum amount of air that can be expelled from the lungs, after first filling the lungs maximally and then releasing them as much as possible. The average normal lung capacity volume is $\pm 4600 \mathrm{ml}$. Lung Capacity Volume is obtained from inspiration reserve results + tidal volume results + expiratory reserve volume results. Every human being has a different average VKP value, the higher the average VKP value of a person, then the person has good breathing and vice versa if the lower the average VKP value of a person, then the person has poor breathing (Guyton, 2007).

The results of this study are in line with research by Syaiful Dwi Jatmiko (2017), it is found that the value of $t$ arithmetic $(0.624)<t$ table $(1,987)$, and $p$ value $=0.534>0.05$, so it can be concluded that there is no significant difference between the levels of vital lung capacity of students who joined futsal extracurricular and basketball extracurricular activities in Purbalingga Regency High Schools.

\section{d. Correlation Analysis of blood glucose with VT, VCI, VCE, VKP in the Damatex Clinic and the UKSW Clinic in Salatiga City.}

Pearson correlation test results found that GD is positively related to VT with a degree of correlation of weak correlation $(r=0.220)$. GD was positively and significantly related $\mathrm{p}=0.017(\mathrm{p}<0.05)$ to VCI with a degree of correlation of weak correlation $(\mathrm{r}=$

Received September $16^{\text {th }} 2019$, Revision January $28^{\text {th }} 2020$, Accepted for publication February $18^{\text {th }} 2020$.

Copyright (C) 2020 Published by FKIP - Unpatti, ISSN 2721-3110 
0.308). GD is negatively related to VCE with degree of correlation correlation is weak ( $\mathrm{r}$ $=-0.110)$. GD is positively related to VKP with the degree of correlation of weak correlation $(\mathrm{r}=0.219)$.

International Diabetes Federation (2012) reports that people with DM are at higher risk for developing tuberculosis than those who are not DM, which is 2.5 times. Research shows that in countries with increased DM prevalence, TB prevalence has also increased. TB and DM are classified in the top 10 causes of death in the world in countries with lower middle income. The health burden due to TB will increase due to the increasing prevalence of DM (Magee M.J, 2011). DM patients who are not controlled will tend to experience bacterial growth, especially the Mycrobacterial and Anaerobic bacteria and Fungi infection. Infection can cause pneumonia, chronic obstructive pulmonary disease, or tuberculosis (TB) in people with DM. Compared to non-DM sufferers, DM sufferers are more prone to suffering from tuberculosis and are more susceptible (around 12.8\%) to TB germ infections, moreover if their DM is uncontrolled, not well maintained (Misnadiarly, 2006).

This study is in line with the results of a study by Meggy et al (2015) about the relationship of blood sugar control with pulmonary function in DM patients in endocrine poly Prof. RSUP Dr. R. D. Kandou manado. Pearson correlation statistical test results show that there is a negative and not significant relationship between $\mathrm{HbAlc}$ levels with VEP $(r=-0.251 ; p=0.181)$ and HbAlc levels with KVP $(r=-0.079 ; p=0.679)$. Therefore it is very important for DM sufferers to normalize blood glucose levels through diet, exercise and medication. Thus the control of blood glucose levels, the function of leukocytes will return to normal, the immune reaction will return to normal, and microangioati will be reduced. Also the levels of free fatty acids, glycerol and amino acids which are growth media for TB germs are decreasing (Corona M.E.J, 2013).

\section{Conclusion}

The results of the lung volume profile study in the DM and Non DM groups in the Damatex Clinic and the UKSW Clinic Salatiga City, can be concluded that:

1. There is a significant difference between GD in DM group and Non DM group with $p$ $=0.021(\mathrm{p}<0.05)$.

2. There are significant differences in VT, VCI, VCE DM group and Non DM group with significant VT values $p=0,000(p<0.05)$, VCI $p=0.003(p<0.05)$ and VCE $p$ $=0.001(\mathrm{p}<0.05)$.

3. There was no significant difference in the VKP of the DM group and the Non DM group with $\mathrm{p}=0.805(\mathrm{p}<0.05)$.

4. There is a positive relationship between GD and VT $(r=0.220)$, GD with VCI $(r=$ $0.308)$, GD with VKP $(r=0.219)$. and there is a negative relationship between GD and VCE $(r=-0.110)$.

\section{References}

ADA. (2010). Diagnosis And Classification Of Diabetes Mellitus Diabetes Care USA. 27: 55

Ahmad Syauqy. (2015). Differences in Fasting Blood Glucose Levels of Diabetes Mellitus Patients Based on Knowledge of Nutrition, Attitudes, and Actions in the Internal Medicine Poly Jakarta Hospital. Indonesian Nutrition Journal, Vol. 3, No. 2;

Alsagaff, H., \& Mukty, H.A. (2005). The Basics of Lung Disease. Third Matter. Surabaya: Airlangga University Press, p.7-11.

Received September $16^{\text {th }} 2019$, Revision January $28^{\text {th }} 2020$, Accepted for publication February $18^{\text {th }} 2020$.

Copyright (C) 2020 Published by FKIP - Unpatti, ISSN 2721-3110 
Amir, S.M.J., Wungouw, H., \& Pangemanan, D. (2015). Blood Glucose Levels When In Patients With Type 2 Diabetes Mellitus In Manado City Health Center. Journal of e-Biomedics (eBm), 3 (1), 32-40.

Azimi-Nezhad, M. et al. (2008). Prevalence of type 2 diabetes mellitus in Iran and its relationship with gender, urbanization, education, marital status and occupation. Singapore Medical Journal 2008; 49 (7): 571

Blondshine. (2000). Spirometry: Asthma and COPD Guidelines Creating Opportunities for RTS "AARC Times: 43-7.

Cahyadi, A. \& Venty. (2011). Lung Tuberculosis in Diabetes Mellitus Patients. J Indon Med Assoc, 61 (4): 173-178.

Corona M.E.J., Hervert L.P.C., Garcia L.G., Reyes L.F., Sanchez G.D., Valley M.B et al. (2013). Association of diabetes and tuberculosis: impact on treatment and posttreatment outcomes. Thorax, 68 (3): 214-220.

Dahlan, S. (2008). Steps to Make a Research Proposal in the Field of Medicine and Health, Jakarta: CV Sagung Seto.

Depkes RI. (2008). Diabetes Mellitus Threats of Humans in the World. Accessed 15 September 2017. Http: www.depkes.go.id/indeks/.

Depkes RI. (2008). Information on disease control and prevention of diabetes mellitus. Jakarta: Directorate General of PPM and PL of the Republic of Indonesia Health Ministry.

Elorriaga, G. \& Pineda, D.R. (2014). Type 2 Diabetes Mellitus as a Risk Factor for Tuberculosis. J Mycobac Dis, 4 (2).

Guyton Athur, C. (2007). Medical Physiology Textbook (Translator: Adji)

IDF. (2012). Diabetes and Tuberculosis. Diabetes Atlas. Sixth edition. (Internet) Available from: $<$ http://www.idf.org/Diabetes Atlas $>$ [access February 13, 2019].

Kemenkes RI. (2018). Prevent, Prevent, and Prevent: World Voice Against Diabetes. Published On: Monday, 10 December 2018 00:00:00, Read: 2,262 Times. http://www.depkes.go.id/article/view/18121200001/prevent-prevent-and-preventthe-voice-of-the-world-fight-diabetes.html.

Livia, R. et al. (2015). Tuberculosis Infection among Diabetes Mellitus Patients in Hasan Sadikin Hospital Bandung, Indonesia. Proceedings of the 4th Indonesia TB Research Parade, March 11-12, 2015. Jakarta: Ministry of Health, Republic of Indonesia.

Magee M.J., Blumberg H.M., Narayan KM.V. (2011). Commentary: Co-occurrence of tuberculosis and diabetes: new paradigm of epidemiological transition. Int. J. Epidemiol, 40 (2): 428-431.

Meggy R. Kowaas., Et al. (2015). Relationship of blood sugar control with pulmonary physiology in patients with diabetes mellitus in Endocrine Poly RSUP Prof. Dr. R. D. Kandou Manado. Journal of e-Clinic (eCl), Volume 3, Number 1. Thesis Candidate Faculty of Medicine, Sam Ratulangi University, Manado Dr. R. D. Kandou Manado E-mail: mkowaas11035@yahoo.co.id.

Misnadiarly. (2006). Ulcer, gangrene, diabetes mellitus infection. Jakarta: Torch Popular Library.

Ndraha, S. (2014). Type 2 Diabetes Mellitus and Current Management. Accessed 10 October 2017, from http://cme.medicinus.co.file.php/1/LEADING ARTICLE Type 2 Diabetes Mellitus and the latest procedures. Pdf

Nursalam. (2011). Nursing Management. Application in Professional Nursing Practices. Salemba Medika: Jakarta.

Pangemanan., Malayu. (2014). Risk Factor Analysis of the Causes of Type 2 Diabetes Mellitus in Productive Age Women in Puskesmas Wawonasa. Journal of eBiomedics (eBM). Volume 2 Number 2.

Received September $16^{\text {th }} 2019$, Revision January $28^{\text {th }} 2020$, Accepted for publication February $18^{\text {th }} 2020$.

Copyright (C) 2020 Published by FKIP - Unpatti, ISSN 2721-3110 
Pearce, Evelyn, C. (2008). Anatomy and Physiology for Medics, Twenty-ninth Printing. Jakarta: PT. Gramedia Main Library, p. 141-142.

PERKENI. (2011). Consensus on the Management and Prevention of Type 2 Diabetes Mellitus in Indonesia.

Sherwood, L. (2001). Human Physiology; from Cell to System. Issue 2. Jakarta; EGC.

Sugiyono (2012). Understanding Quantitative Research. Bandung: ALFABETA.

Sudoyo, Aru W., Bambang Setyohadi, Idrus Alwi, Marcellus Simadibrata, Siti Setiati. (2009). Book of Medicine in Disease Edition 5. Jakarta: Interna: 1873-85.

Sutanto. (2010). Diabates Mellitus is a disease caused by lifestyle. http: // yuwie.com. Accessed January 16, 2019.

Syaiful Dwi Jatmiko. (2017). The difference in the lung vital capacity of students who take futsal extracurricular activities and basketball extracurricular activities in Purbalingga District Public High Schools Health and Recreation Physical Education Study Program, Department of Physical Education, Faculty of Sports Science, Yogyakarta State University. E-JOURNAL, Email: syaifuldwij@gmail.com. Accessed January 16, 2019.

Taylor, C., Lillis, C., Lemone, P., \& Lynn, P. (2010). Fundamentals of nursing: The Art and Science of Nursing Care (7th). Philadelphia: Lippincott Williams \& Wilkins.

Received September $16^{\text {th }} 2019$, Revision January $28^{\text {th }} 2020$, Accepted for publication February $18^{\text {th }} 2020$.

Copyright (C) 2020 Published by FKIP - Unpatti, ISSN 2721-3110 